\title{
Customer loyalty and switching behavior of customer for Pepsi in Pakistan
}

\author{
Khadim Hussain \\ Research scholar, Department of Management Sciences, \\ The Islamia University of Bahawalpur, Pakistan \\ E-mail: sajidwaince@gmail.com \\ Muhammad Rizwan \\ MS Scholar, Department of Management Sciences \\ The Islamia University of Bahawalpur, Pakistan \\ Email: rizwan.arshad@iub.edu.pk
}

Accepted: June 18, 2014

Doi:10.5296/ jpag.v4i2.5841 URL: http://dx.doi.org/10.5296/ jpag.v4i2.5841

\begin{abstract}
Intention to switch from one service provider to another, leads to switching behaviour, which results in the decrease of profits of the company. Switching behaviour helps in creating relationship between consumer and producer. In this research we study and investigate the effect of switching behaviour, customer satisfaction, habit, and utilitarian values on customer loyalty. The customer satisfaction, habit and utilitarian value were determined to be input variables, switching behaviour were determined to be intervening variables; and customer loyalty was determined to be the output variable. The model was designed to explain the factors affecting the customer loyalty. Our study based on a self-administered survey that was conducted in Bahawalpur setting. Data were collected from the randomly selected 150 Pepsi product consumers. Our study results provide a better understanding about the role played by each factor in the development customer loyalty and highlights the key role played by affective factors.
\end{abstract}

Keywords: Bahawalpur, Customer loyalty, utilitarian values, customer satisfaction, Pepsi cola 


\section{Introduction}

Building long lasting relations with customers has become a critical strategy for organizations in nowadays competitive markets. Customers built intention to switch from one organization to another if their needs are not satisfied. Firms can raise customer satisfaction by increasing the remuneration that they are providing with the product or services Shift behaviour helps in making relationship between client and producer. During this analysis we have a tendency to study and investigate the impact of shift behaviour, client satisfaction, habit, and utilitarian values on client loyalty. The client satisfaction, habit and utilitarian worth were determined to be input variables, shift behaviour were determined to be intervening variables; and client loyalty was firm to be the output variable. The model was designed to clarify the factors poignant the client loyalty. Our study supported a self-administered survey that was conducted in Bahawalpur setting. Data was collected from the willy-nilly chosen one hundred fifty dope product shoppers. Our study results offer a stronger understanding regarding the role compete by every think about the event client loyalty and highlights the key role complete by emotional factors. Consumers use service a day. It includes all sort of services whether or not taking a train or gap a brand new checking account or speech on telephone. Businesses essentially depends on wide ranges of merchandise and services that area unit used when on a day, however these services aren't as same as a client use on day after day whether or not these acts on a way larger scale. But it's the psyche of a client that he's not invariably glad with the advantages against he pays rather those area unit merchandise or services and therefore the client is often keen to resort its satisfaction by shift towards a more cost-effective product or service that peruses its higher price. In competitive market of today's retail it to you has become a tough task for each supplier to satisfy its client therefore on develop an extended term relationship and might aforementioned to be as essential issue among the organization to create such sort of relation. It's quite obvious that if customer's desires aren't consummated then he can switch towards another organization. Customer's satisfaction may be increased by the corporations if they increase the advantages and remuneration that they get by exploitation specific product or service.

Acquisition of latest client is sort of big-ticket technique rather than retentive the regular client. The complete ought to be up to standards so no client switches towards another different. The complete should be as credible to retain its place within the market. A client satisfaction is that the key think about rising client connotation towards the services supplier by the organization. There's an additional price needed to draw in a replacement client towards your product if the prevailing client switches or deviates. The prevailing clients are the key customers thus it's necessary for each organization to take care of its customer instead of getting the new one. For the expansion and survival of agency service the service quality is alleged to be as essential success issue. In any competitive market the top quality service provided to client isn't solely having competitive advantage however it additionally differentiates it from the opposite services firm. Perception of quality among a company towards the service provided is troublesome to mount owing to impalpability and heterogeneousness related to the similar service provided. Establishing long run relationship with customer's square measure aforesaid to be as essential factors for nearly each 
organization and also the service provided. Each organization has some hidden agenda by that they will increase their profits. The corporate or organization that delivers performance over and better than the patrons expectation area unit aforementioned to be as a result of the triple-crown organizations, An oversized investment is spent on the promotions simply to extend the customer's satisfaction method, if the shoppers' expectation aren't consummated then it ends up in the discontentment if the customers. If performance of the merchandise matches the expectation of the client then the client is glad. In delightedness of the client the merchandise exceeds the expectation of the client. Semi-permanent satisfaction ends up in client retention or we will say loyalty. Quality of product could be a main issue owing to that the client tends to change its behavior. If an organization doesn't provide its client with the standard product then the client are going to be disgruntled and due discontentment he can switch to the opposite different product for his satisfaction. customer satisfaction is a vital topic for nearly each supplier of service, and is believed to be related to enlarged revenue and reduces value (Reichheld 1993; Reichheld and Sasser, 1990).customer satisfaction and change behaviors are relevant antecedents of client's loyalty, and their role in making the loyalty receives substantial attention within the literature ( designer et al., 2003; Jones et al., 200020022007 : Patterson and smith, 2003; Wieringa and Vehrof , 2007 : rule and Peterson, 2004).

In light-weight of the restricted investigation into shopper loyalty behaviour within the written agreement service setting, the current paper contributes to the literature in 3 outstanding aspects. First, the study replicates earlier studies on the consequences of satisfaction, and their interaction on each client loyalty and client satisfaction. The rest of this paper begins with a review of literature that evaluates the role of change behaviour in loyalty formation. In-services selling literature, shift remains prime focus in relationship selling idea (Oliva et al., 1992; reichheld, 1993). On the contrary, it's a negative result on client shift intentions (Mittal \& Lassar, 1998; hennig-thurau et al., 2002).

However many times this relationship is plausible, a client will switch not withstanding being happy. Johns \& Sesser discovered that the connection between satisfaction and loyalty is neither linear nor easy. Many times high level of satisfaction go hand-in-hand with continuous increase in client defection and also the reason don't seem to be thus clear. Being the primary few to elucidate the connection of relationship paradigms, reichheld \& Sasser declared that companies may retain client either by outperforming the competitors by making a special interaction with the purchasers through their selling processes and may increase their advantages and profits.

\section{Literature Review:}

\subsection{Customer Loyalty}

Customer loyalty was approached preponderantly in client behavior analysis from a behavioral perspective for a protracted time (et al., 1996; Oliver, 1999; Zeithaml Raju et al., 1990; Pessemier, 1959; Rundle-Thiele and Mackay, 2001). Jones and Sasser (1995, p. 94) declared that client loyalty is "a feeling of attachment to or heart for a company's folks, products, or services”. Dick and Basu (1994) supplemented the behavioral approach with 
the conception of relative angle that reflects the degree to that the customer's analysis of 1 service dominates that of another. They thoroughbred that true loyalty solely exists once repeat patronage coexists with a high relative angle.

Therefore, client loyalty is approached as Associate in nursing attitudinal construct (Ajzen and Fishbein, 1980). So“derlund (2006) used repatronage intentions and spoken intentions as a set of loyalty intentions. This distinction between action and speak may be a vital issue in structure theory (Feldman and March, 1981). Supported a good angle towards a service supplier, customers could develop preference loyalty. Preference loyalty will add 2 wys in which. The client could consult the web site if s/he needs to create an acquisition (action), or to suggest it to others (talk). Except for preference loyalty, American state Hans Conrad Julius Reiter et al. (1998) conjointly found worth indifference and discontent response, each would have an effect on client loyalty whereas they conducted investigations in health centers (hospitals, physiatrist and treatment clinics) and town theaters (including opera houses). However, worth indifference might not be acceptable for e-commerce to use for activity client loyalty, as a result of competitive worth is that the main reason for internet buyers purchased on the net (Ernst \& Young, 2000). Besides, not like health centers or theaters, customers will freely purchase product or services form varied suppliers; however skilled doctors for patients or distinctive opera for audiences each cannot be substituted. Therefore, we have a tendency to infer that customers could have the disposition to pay a premium worth for suppliers on the net. For discontent response, Hirschman (1970) argued that a dissatisfied client has essentially 2 choices for a negative (service) expertise, one is discontinuing the connection (exit) and also the alternative is communication discontent (voice). As usual, dissatisfied customers can voice their complaints to the service supplier (e.g. via a toll free number), its workers or external agencies like client organizations. Therefore, discontent response may be a construct of client loyalty for e-commerce as a result of we are able to simply browse several positive or negative comments from on-line client experiences denote on totally different websites. The upper the discontent response is, the lower the client loyalty. Hence, discontent response may be a negative indicator of client loyalty, whereas preference loyalty may be a positive indicator of client loyalty.

\subsection{Switching Behaviour}

Literature on client switch (or churn) has investigated its potential antecedents (e.g. Dick and Basu, 1994; Bolton et al., 2004), wherever Keaveney (1995) was the first to introduce the model of client switch behaviour, containing eight main casual factors that area unit essential to switch behaviour, namely, pricing, inconvenience, core service failures, service encounter failures, worker responses to service failures, competitive problems, moral issues and involuntary factors. Among these antecedents, rating drawback emerged because the most influential issue for switch followed by service failures and denied services (Colgate and Hedge, 2001).

Although, switch behavior additionally seems in theory, wherever economic students approach switch prices as a mean for keeping customers in relationships (Wieringa and Verhoef, 2007), despite their satisfaction with the supplier (e.g. Jones et al. 2000; Lee et al., 
2001; Daniel Hudson Burnham et al., 2003; Bansal et al., 2004; Yanamandram and White, 2006). A lot of notably, procedural switch price enhances calculating commitment, that after will increase repurchase intention and reduces undesirable emotions, negative viva-voce and ultimately, switch (Jones et al., 2007; Khan et al., 2010). This becomes essential as a result of if customers were able to switch simply, operators would be less inclined to charge too high costs or provide poor quality of services (Xavier and Ypsilanti, 2008). Searching more, Daniel Hudson Burnham et al. (2003) declared that switch prices generate passive loyalty, whereas switch barriers prompt relationship-improving investments (Yen, 2010). Moreover, switch barriers aren't solely absolutely poignant the client retention however additionally playing associate degree adjustment impact on core service quality and satisfaction on the one hand (Chen and Wang, 2009) and satisfaction and loyalty on the opposite (Ranaweera and Prabhu, 2003; Kim et al., 2004). Beside relative investments, service recovery and various attractiveness, switch prices is additionally one among the foremost necessary classes of switch barriers (Colgate and Lang, 2001). Surviving literature reveals that the character and extent of switch behavior within the banking sector has not been middling studied. An honest deal of analysis work has been restricted to varied relative factors, therefore neglecting different facet of switch behavior (Bansal et al., 2004; Yavas et al., 2004; Jones et al., 2007; Chen and Wang, 2009; Liang et al., 2009). Whereas studies like Keaveney (1995); Colgate and Hedge (2001); Daniel Hudson Burnham et al. (2003); Wieringa and Verhoef (2007); Matos et al. (2009); Khan et al. (2010); strained themselves to at least one or the opposite side of switch. Inside this big selection of researches, little attention has been given to why and once exchange relationship ends, particularly with relation to client relationship in services (Halinen and Tahtinen, 2002; Akerlund, 2005). However, study conducted by Bansal et al. (2005) is associate degree exception that by trial and error explored the relevance of push-pull-mooring (PPM) paradigms. Inside this massive paradigm, client loyalty has been neglected, that may be a basic part of switch behaviour. Further, they restricted their study to car repair and hair styling services, findings of that can't be generalized to the financial sector.

Thus, this study explores the key factors contributive to client switch and examines the link between relationship selling paradigms and switch intentions in context to Indian banking. Further, it investigates the impact of relative factors on switch barriers.

\subsection{Customer satisfaction}

Customer satisfaction, a business term, could be a live off however merchandise and services equipped by a corporation meet or surpass client expectation. However, that appears off once you cross-check the separate definitions of the 2 words that comprise the term. Client satisfaction is associate overall angle shaped supported the expertise once customers purchase a product or use a service (Fornell, 1992). It's a reflection of being content with such a product or a service. Satisfaction is that the assessment of the expertise of interacting with a service supplier up to the current time, and is employed by customers to predict future expertise (Crosby et al., 1990). Satisfaction could be a broad feeling that is suffering from service quality, product quality, price, and discourse and private factors (Zeithaml \& Bitner, 2000). Satisfaction is one among the antecedents of client loyalty. In previous studies, satisfaction absolutely affects client loyalty (de Ruyter \& Wetzels, 2000; Deng, Lu, Wei, \& 
Zhang, 2009; Dick \& Basu, 1994). Though the rationale that customers stay loyal might not invariably be satisfaction (Gerpott, Rams, \& Schindler, 2001), it's safe to mention that satisfied customers area unit a lot of loyal. In term of service quality dimensions within the monetary services trade, are numerous dimensions have been discovered. Parasuraman et al. (1985), as an example, establish eleven dimensions of service quality that area unit dependability, responsiveness, competence, access, courtesy, communication, credibleness, security, competence, understanding the client, and tangibles. However, based mostly upon their findings, Berry et al. (1985) and Zeithaml and Bitner (1996) indicate that service quality consists of 5 dimensions that area unit tangibles (appearance of physical facilities, equipment, personnel, and written materials), dependability (ability to perform the secure service faithfully and accurately), responsiveness (willingness to assist customers and supply prompt service), assurance (knowledge and courtesy of staff and their ability to inspire trust and confidence), and sympathy (caring and individual attention the firm provides its customers). There area unit several benefits for a corporation from a high client satisfaction level. It heightens client loyalty and prevents client churn, lowers customers' value sensitivity, reduces the prices of unsuccessful promoting and of latest client creation, reduces operative prices attributable to client variety will increase, improves the effectiveness of advertising, and enhances business name (Fornell, 1992).

The main issue crucial client satisfaction is that the customers' own perceptions of service quality (Zeithamal \& Bitner, 1996). During this study, we have a tendency to shall define service quality because the customers' satisfaction or discontent shaped by their expertise of purchase and use of the service (Parasuraman, Zeithamal, \& Berry, 1988).

In earlier studies on mobile telecommunication services, service quality has been measured by decision quality, evaluation structure, mobile devices, added services, convenience in procedures, and client support (e.g., Kim, 2000; Gerpott et al., 2001; Lee, Lee, \& Freick, 2001; Rizwan et al., 2013).

\subsection{Habit}

The role of habit is one vital antecedent of switch behavior that the present literature has nevertheless thought-about. Habits characterize the ways that within which behaviors concerned in employing an explicit service become more and more automatic as a consequence of continual expertise thereupon service (Murray \& Haubl, 2007). Consequently, habits are a vital antecedent of each economic and social switch barriers, and become a consequence of repeat use of explicit product or service. Additionally habits are associate economical technique of preventing customer's psychological feature efforts to settle on (Murray \& Haubl, 2007) and therefore the routine of habits, like reading the morning News Paper is helpful and comforting (Bentley, 2000). While this paper indicates that however habit effects the getting behaviour of a client towards a product thus on build it's helpful in his sight whether or not to maximize its advantages or simply to satisfy its motive. It doesn't means habit is that the solely issue to influence the switch behavior towards a particular product it's so an analgesic worth that enhances the consequences of switch thus by considering it as a variable we have a tendency to appears to be evaluating several answers from it thus on modify our literature. 


\subsection{Utilitarian Value:}

Value is that the subject's analysis when his or her interaction expertise with issue or events, it's a key outcome variable during a general model of consumption experiences (Babin et al : 1994 ; Holbrook and Corfman, 1985).

Utilitarian price results from the aware pursuit of Associate in Nursing meant consequence (Babin et al:. 1994). It is primarily instrumental, functional, psychological feature Associate in Nursing represents client price as suggests that to an finish (Chandon et al:.. 2000).for example, savings , convenience, Associate in Nursing product quality will be classified as utilitarian values (Ailawadi et al;.. 2001: Cahndon et al;..2000: Chaudhari and Halbrook, 2001. Historically marketers believed that markets elections and shopper preferences were driven by utilitarian price (Arnould et al; 2004). Utilitarian price somehow provides some kind of financial and satisfaction advantages. IT holds each the tangible and intangible joys rather it's with the exception of the values of fun, joy, sorrow or emotion fullness. Utilitarian values are with the exception of the emotions it's simply the reason behind beneficial value.

\subsubsection{H1: habit has an influencing effect on switching behaviour of customer}

Habit is a factor which lies into a customer and is said to be a key factor to influence a customer behaviour or attitude to gain its attention towards an alternative so as to avoid some sort of repeated consequences of a same product.

\subsubsection{H2: Utilitarian values are positively related with Customer's satisfaction}

The sense of being prioritize by using its pricing gives pleasure to a customer so as monetary benefits are satisfactory points for a customer then it can be said that the utilitarian values are having positive effect on customer satisfaction which leads toward switching behaviour towards a particular or habitual product.

\subsubsection{H3: There is a negative relation between switching behaviour and customer Loyalty}

It can be perceived that switching behaviour and customer loyalty are opposite to each other and can be said as reciprocal of each other. If one of the factor is increasing then it is obevious that the other factor will go on decreasing.

\subsubsection{H4: There is a positive relation between the customer satisfaction and customer loyalty}

Customer loyalty is the factor that explains that it is "a feeling of attachment to or affection for a company's people, products, or services in a customer's mind".so this hypothesis explains that if a customer is having a positive attribute towards a product then he will hardly switch to other alternative is will said to be as loyal.

\subsubsection{H5: Utilitarian value has a direct effect on customer loyalty}

If a product is fulfilling the requirements and the monetary values of a customer then the customer will be loyal towards that product. 


\section{Macrothink}

\subsubsection{H6: Utilitarian value is having a negative relation with switching behaviour}

\subsection{Research Model}

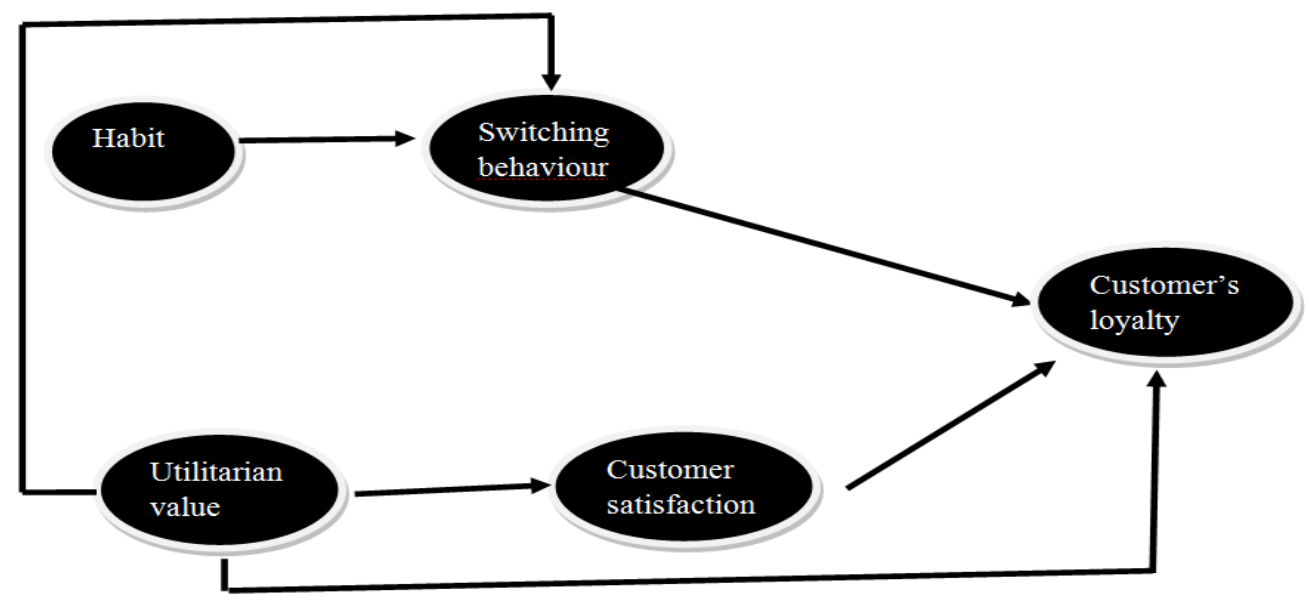

\section{Research Methodology}

The nature of current study is descriptive that explains the full development. Descriptive analysis may be explained on describing one thing, some development or any specific scenario. In Descriptive analysis we have a tendency to explain the phenomena or scenario not any style of interpretation happens within the descriptive analysis. (Creswell.1994). the primary purpose of the descriptive analysis is verification of the developed hypotheses that mirror the present scenario. This sensible and descriptive study shows the dependability of the form.

\subsection{Sample/Data}

A sample of a hundred and fifty dope users was indiscriminately elite, for this purpose the study based mostly and developed through conducting self-administered questionnaires. the info was collected from Bahawalpur town and shoppers were asked to participate during this analysis to gather the data regarding shift behavior. this study utilizes a non-probability sampling technique that's convenience sampling. it's a sampling technique within which information or relevant info is collected from the sample/units of the study that square measure handily on the market (Zikmund, 1997)

\subsection{Questionnaire and Scales}

There are two major purposes of the survey instrument: first to investigate the relationship of different variables in foundation of switching behavior and secondary, to gather the information about the respondents of different characteristics that can be used to understand the variations in different classes.

The survey of the study contains two sections. Section 1 contains individual specific and 


\section{Macrothink}

demographic variables. This section tells the respondents gender, age, income, education and status.

While Section 2 includes the variables that are under study these variables include switching behavior, customer satisfaction, Utilitarian value, customer loyalty and habit. The base of this section is on the past literature and already builds and used questionnaires.

\subsection{Table 1: Scales of the study}

\begin{tabular}{|c|c|c|c|}
\hline No & Variables & Items & Reference \\
\hline 1 & Customer loyalty & $\begin{array}{l}\text { This brand would be my first choice. } \\
\text { I consider myself to be loyal to this } \\
\text { brand. } \\
\text { I recommend this brand to someone who } \\
\text { seeks my advice. } \\
\text { I get good value for my money. } \\
\text { I say positive things about this brand to } \\
\text { other people. } \\
\text { I am willing to pay premium price over } \\
\text { competing products to be able to } \\
\text { purchase this brand again. } \\
\text { I consider this brand my first choice in } \\
\text { the next few years. }\end{array}$ & $\begin{array}{l}\text { (Algesheimer, Uptal } \\
\text { and Herrmann, } 2005\end{array}$ \\
\hline 2 & Utilitarian values & $\begin{array}{l}\text { Using this brand was convenient } \\
\text { Using out particular brand was pragmatic } \\
\text { and economical } \\
\text { It was not waste of money when using } \\
\text { this brand } \\
\text { Service at the fast-casual restaurant was } \\
\text { quick }\end{array}$ & Fullerton, 2005 \\
\hline 3 & Switching behavior & $\begin{array}{l}\text { I intend to switch my service provider } \\
\text { Next time I shall need services of other } \\
\text { provider } \\
\text { I would not continue to have service } \\
\text { from my current service provider }\end{array}$ & \\
\hline
\end{tabular}




\begin{tabular}{|l|l|l|l|}
\hline 4 & $\begin{array}{l}\text { Customer } \\
\text { satisfaction }\end{array}$ & $\begin{array}{l}\text { 1.Overall I am satisfied with specific } \\
\text { experience with the brand } \\
2 . \mathrm{I} \text { am satisfied with my decision to } \\
\text { purchase from this brand }\end{array}$ & $\begin{array}{l}\text { Ragunathan } \\
\text { Irwin(2001) }\end{array}$ \\
\hline 5 & Habit & $\begin{array}{l}\text { I consume a Pepsi once in a day } \\
\text { I consume a Pepsi once in a week }\end{array}$ & $\begin{array}{l}\text { Murray \& Haubl, } \\
2007, \text { (Bentley, 2000 }\end{array}$ \\
\hline
\end{tabular}

\subsection{Procedure}

The questionnaire was distributed among 170 respondents for collection of data in Bahawalpur. From the above mentioned criteria the respondents were selected for this purpose. From the starting point or before giving the questionnaire the purpose of the research and study was described to them so that they can easily fill up the questionnaire with appropriate response answers. After the collection of data 150 questionnaires were selected and rest of the questionnaires were not including in the research due to invalid and incomplete questionnaires. The setting of the variables were according to the five point Liker scale $(1=$ strongly agree, $2=$ agree; $3=$ neutral, $4=$ disagree; $5=$ strongly disagree). Data was codded in SPSS programmed. To view the results regression analysis was used

\subsection{Reliability Analysis:}

All the variables are reliable because the cornback alphas of the the variables are above the value of 0.50 Nunnaally (1970) and 0.60 by Moss el al (1998). This shows that all the 31 items were reliable and suitable to compute the opinions of customers towards switching behavior.

\subsubsection{Table: Reliability of Measurements Instrument}

\begin{tabular}{|l|l|l|}
\hline Scales & Items & Cronbach Alpha \\
\hline Customer loyalty & 7 & 0.631 \\
Utilitarian values & 3 & 0.792 \\
Customer satisfaction & 2 & 0.634 \\
Switching behavior & 3 & 0.704 \\
Habit & 2 & 0.585 \\
\hline
\end{tabular}




\section{Hypothesis Testing}

\subsection{Sample}

The respondents personal and demographic collected information such as gender, age, income, education and status are given in the following constructed table (Table 2)

Table 2: Description of the Respondents

\begin{tabular}{|c|c|c|c|}
\hline & Category & Frequency & Percentage \\
\hline \multicolumn{4}{|l|}{ Variable } \\
\hline \multirow[t]{2}{*}{ Gender } & Male & 109 & 72.7 \\
\hline & Female & 41 & 27.3 \\
\hline \multirow[t]{5}{*}{ Age } & $15-20$ years & 53 & 35.3 \\
\hline & 20-25 years & 84 & 56.0 \\
\hline & 25-30 years & 09 & 06.0 \\
\hline & 30-35 years & 03 & 02.0 \\
\hline & Above 40 & 01 & 0.7 \\
\hline \multirow[t]{4}{*}{ Income } & Below 15000 & 101 & 67.3 \\
\hline & $15000-35000$ & 26 & 17.3 \\
\hline & $35000-40000$ & 13 & 08.8 \\
\hline & Above 40000 & 10 & 6.7 \\
\hline \multirow[t]{5}{*}{ Education } & Matriculation & 09 & 6.00 \\
\hline & Inter & 16 & 10.7 \\
\hline & Bachelor & 100 & 66.7 \\
\hline & Master & 18 & 12.00 \\
\hline & Ms/MPhil & 07 & 4.71 \\
\hline \multirow[t]{2}{*}{ Status } & Student & 115 & 76.7 \\
\hline & Employed & 35 & 23.3 \\
\hline
\end{tabular}


4.2. Utilitarian values, customer's satisfaction, switching behavior and customer loyalty

In order to understand the model of switching behavior regression results show that there is significant positive relationship between utilitarian values and customer loyalty with $(\beta=.563)$ and $(\mathrm{p}<0.00)$. This means that utilitarian value helps more than $56 \%$ to create customer loyalty among customers. Our study validates the hypothesis H5

The regression analysis of the study shows that there is a positive significant relationship between customer satisfaction and customer loyalty with $(\beta=.638)$ and $(p<0.00)$. Through this result we came to know that customer satisfaction contribute more than $63 \%$ to create customer loyalty. From this result we can say that our study supported the hypothesis H4.

Furthermore the relationship between switching behavior and customer loyalty is significant and negative with $(\beta=.563)$ and $(\mathrm{p}<0.00)$. According to this regression analysis result we came to know that switching behavior contribute more than $56 \%$ in decreasing customer loyalty among customers. So this result gives validation in favors of hypothesis H3.

The relationship between utilitarian values and switching behavior is significant and negative with $(\beta=.573)$ and $(\mathrm{p}<0.00)$. According to this regression analysis result we came to know that utilitarian values contribute more than $57 \%$ in decreasing switching behavior among customers. So this result gives validation in favors of hypothesis H6.

\subsection{Habit and switching behavior}

Regression analysis of our research shows that there is a positive and significant relationship between habit and switching behavior with $(\beta=.552)$ and $(\mathrm{p}<0.0 \mathrm{o})$. This outcome tells that habit contribute more than $55 \%$ in switching behavior. Hypothesis $\mathrm{H} 1$ authenticates through this regression outcome. So a relationship between habit and switching behavior is found.

\subsection{Utilitarian values and customer satisfaction}

According to the research study the variables investigated and have a significant positive relationship between utilitarian values and customer satisfaction. Moreover Utilitarian values has a positive effect on customer satisfaction with $(\beta=.723)$ and $(p<0.00)$. This represents that utilitarian values contribute $72 \%$ to customer satisfaction. So, this regression analysis shows that utilitarian values have positive impact on customer satisfaction and which authenticate the hypothesis $\mathrm{H} 2$. 


\section{Macrothink}

Table 4: Results of Hypothesis

\begin{tabular}{|c|c|c|c|c|c|c|}
\hline Hypothesis & Model variables & Estimate $(\beta)$ & S.E & C.R (t) & P & Results \\
\hline H1 & H $\longrightarrow$ S.B & 0.552 & 0.112 & 8.049 & 0.00 & supported \\
\hline H2 & U.V $\longrightarrow$ C.S & 0.723 & 0.039 & 12.726 & 0.00 & supported \\
\hline H3 & S.B $\longrightarrow$ C.L & 0.563 & 0.093 & 8.297 & 0.00 & supported \\
\hline H4 & C.S $\longrightarrow$ C.L & 0.638 & 0.122 & 10.074 & 0.00 & supported \\
\hline H5 & U.V $\longrightarrow$ C.L & 0.658 & 0.081 & 10.642 & 0.000 & Supported \\
\hline H6 & U.V $\longrightarrow$ S.B & 0.523 & 0.067 & 7.470 & 0.000 & supported \\
\hline
\end{tabular}

\subsection{Structural Research Model}

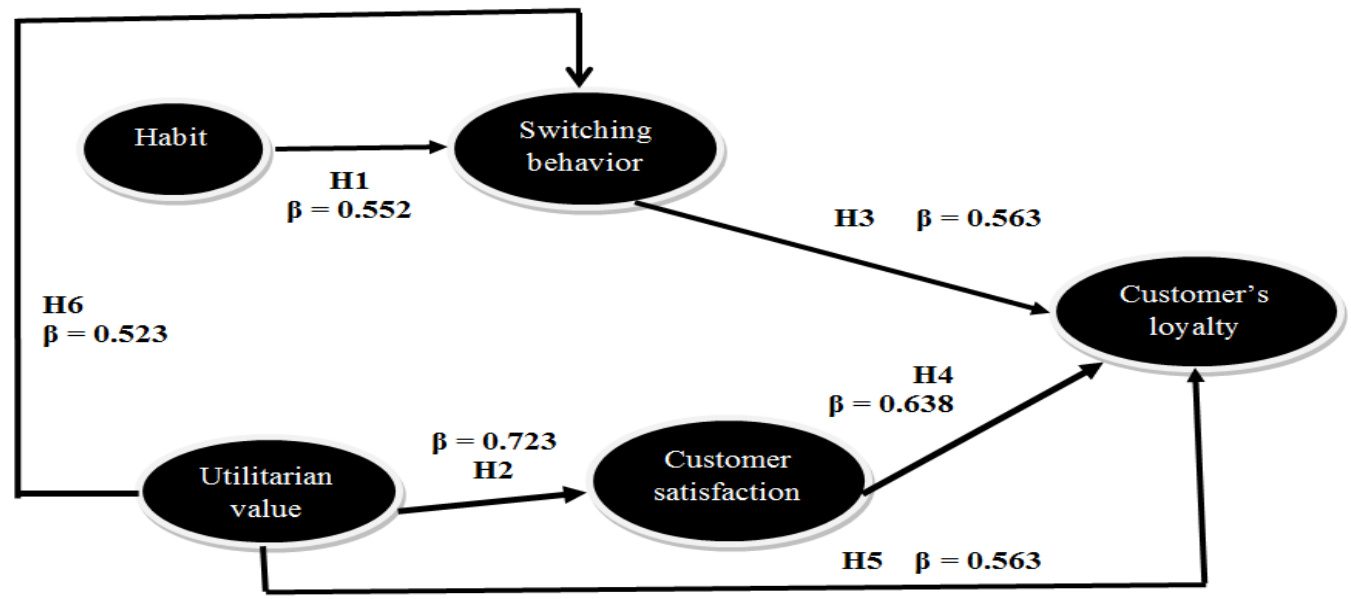

\section{Discussion}

The purpose of the study was to examine the customer's loyalty towards the cold drink pepsi within the competitive market of Bahawalpur where it has to face many other potential competitors. As we can say that with having a vast category of customers loyalty performance check it is said to be as dependent on many variables which are relatively discussed in this paper and are said to be as Habit, Utilitarian value related to the monetary values of the product as well as the emotional benefits of the customer and the main factor that effects the customer loyalty is customer satisfaction and in the market of this region and it is not easy for our product to survive in the market. 
Previous researches shows a significant effect of customer satisfaction on customer's loyalty in our study the research shows that customer satisfaction is the key factor to check the customers loyalty with a significant value of beta. To make customers loyal Companies keep the needs and wants of the customers in mind to satisfy and facilitate them by their best products and services. The study affirmatively proved by this consequence that Brand loyalty can increased by the satisfaction of customer and repeat the purchase of the same product services (LaBarbera and Mazursky, 1983).

The results of the entire hypotheses are being supported with significant values or not are briefly discussed in the paper to make it as easy for further researchers to accomplish their goals and mottos.

\section{References}

Aydin, S. and zer, G. (2005), "How switching costs affect subscriber loyalty in the Turkish mobile phone market: an exploratory study", Journal of Targeting, Measurement and Analysis for Marketing, Vol. 14 No. 2, pp. 141-55.

Ajzen, I. (1985). From intentions to actions: A theory of planned behavior. In J. Kuhl \& J. Beckmann (Eds.), Action-control: From cognition to behavior (pp. 11-39). New York: Springer.

Ajzen, I. (1991). The theory of planned behavior. Organizational Behavior and Human Decision Processes, 50(2), 179-211.

Ajzen, I. and Fishbein, M. (1980), Understanding Attitudes and Predicting Social Behavior, Prentice-Hall, Englewood Cliffs, NJ.

Bamberg, S., Ajzen, I., \& Schmidt, P. (2003). Choice of travel mode in the theory of planned behavior: The roles of past behavior, habit, and reasoned action. Basic and Applied Social Psychology, 25(3), 175-187.

Bamberg, S., \& Schmidt, P. (2003). Incentives, morality or habit? Predicting students' car use for university routes with the models of Ajzen, Schwartz and Triandis. Environment and Behavior, 35(2), 264-285.

Bauer, R.A. (1960), “Consumer behavior as risk taking”, in Hankcock, R.S. (Ed.), Dynamic Marking for a Changing World, American Marketing Association, Chicago, IL, pp. 389-98.

Bolton, R. and Bronkhorst, T. (1995), "The relationship between customer complaints to the firm and subsequent exit behavior", in Kardes, F.R. and Sujan, M. (Eds), Advances in Consumer Research, Vol. 22, Association for Consumer Research, Provo, UT, pp. 94-100.

Bolton, R.N., Lemon, K.N. and Verhoef, P.C. (2004), "The theoretical underpinnings of customer asset management: a framework and propositions for future research", Journal of the Academy of Marketing Science, Vol. 32 No. 3, pp. 271-92.

Boote, J. (1998), “Towards a comprehensive taxonomy and model of consumer complaining 
behavior", Journal of Customer Satisfaction, Dissatisfaction and Complaining Behavior, Vol. 11, pp. 141-9.

Burner, G.C. \& Kumar, A. (2005). Explaining consumer acceptance of handheld Internet devices. Journal of Business Research, 58(5), 553-568

Burnham, T.A., Frels, J.K. and Mahajan, V. (2003), "Consumer switching costs: a typology, antecedents and consequences", Journal of the Academy of Marketing Science, Vol. 31 No. 2, pp. 109-26.

Cox, D.F. (1967), "Risk handling in consumer behavior - an intensive study of two cases", in Cox, D.F. (Ed.), Risk-taking and Information Handling in Consumer Behavior, Harvard University Press, Boston, MA. De Ruyter, K., Wetzels, M. and Bloemer, J. (1998), "On the relationships between perceived service quality, service loyalty and switching costs", International Journal of Service Industry Management, Vol. 9 No. 5, pp. 436-53.

Caruana, A. (2002), "Service loyalty: the effects of service quality and the mediating role of satisfaction”, European Journal of Marketing, Vol. 36 Nos 7/8, pp. 811-28.

Colgate, M. and Hedge, R. (2001), "An investigation into the switching process in retail banking services", International Journal of Bank Marketing, Vol. 19 No. 5, pp. 201-12.

Colgate, M. and Lang, B. (2001), "Switching barriers in consumer markets: an investigation of the financial services industry", Journal of Consumer Marketing, Vol. 18 No. 4, pp. $332-47$.

Colgate, M., Tong, V.T., Lee, C.K. and Farley, J.U. (2007), "Back from the brink: why customers stay", Journal of Service Research, Vol. 9 No. 3, pp. 211-28.

Davis, F. D. (1989). Perceived usefulness, perceived ease of use, and user acceptance of information technology. MIS Quarterly, 13(3), 319-340.

Carter, M., Klein, R., Thatcher, J.B. and Wright, R. (2009), "Switching costs and loyalty: understanding how trust moderates online consumers' ties to merchants", Proceedings of the 8th Annual Workshop on HCI Research in MIS, Phoenix, Arizona. Caruana, A. (2004), "The impact of switching costs on customer loyalty: a study among corporate customers of mobile telephony", Journal of Targeting, Measurement and Analysis for Marketing, Vol. 12 No. 3, pp. 256-68.

Creswell, J.W. (1994) Research Design: Qualitative \& Quantitative Approaches. London: SAGE Publications.

Dick, A.S. and Basu, K. (1994), "Customer loyalty: toward an integrated conceptual framework", Journal of the Academy of Marketing Science, Vol. 22 No. 2, pp. 99-113.

Fishbein, M., \& Ajzen, I. (1975). Belief, attitude, intention and behavior: An introduction to theory and research. Reading, MA: Addison-Wesley. Fornell, C., \& Larcker, D. F. (1981). Evaluating structural equations with unobservable variables and measurement form. Journal of Marketing Research, 18(1), 39-50. 
Fornell, C. and Larcker, D.F. (1981), "Evaluating structural equation models with unobservable variables and measurement error", Journal of Marketing Research, Vol. 18 No. 1, pp. 39-50.

Garland, R. (2002), "Estimating customer defection in personal retail banking, International Journal of Bank Marketing, Vol. 20 No. 7, pp. 317-24.

Jackson, B.B. (1985), Winning and Keeping Industrial Customers: The Dynamics of Customer Relationships, DC Heath and Company, Lexington, MA. Hu, A.W. and Hwang, I. (2006), "Measuring the effects of consumer switching costs on switching intention in Taiwan mobile telecommunication services", The Journal of American Academy of Business, Vol. 9 No. 1, pp. 75-85.

Jones, T.O. and Sasser, W.E. (1995), "Why satisfied customer defect", Harvard Business Review, Vol. 73 No. 6, pp. 89-99.

Jones, M.A., Mothersbaugh, D.L. and Beatty, S.E. (2000), "Switching barriers and repurchase intentions in services", Journal of Retailing, Vol. 76 No. 2, pp. 259-74.

Keaveney, S.M. (1995), "Customer switching behavior in service industries: an exploratory study", Journal of Marketing, Vol. 69, April, pp. 71-82.

Keaveney, S.M. (1995), "Customer switching behavior in service industries: an exploratory study”, Journal of Marketing, Vol. 59 No. 2, pp. 71-82.

Lee, J., Lee, J. and Feick, L. (2001), "The impact of switching costs on the customer satisfaction-loyalty link: mobile phone service in France", Journal of Services Marketing, Vol. 15 No. 1, pp. 35-48.

Lee, J., Lee, J. and Feick, L. (2001), "The impact of switching costs on the customer satisfaction-loyalty link: mobile phone service in France", Journal of Services Marketing, Vol. 15 No. 1, pp. 35-48.

Morgan, R.M. and Hunt, S.D. (1994), "The commitment-trust theory of relationship marketing”, Journal of Marketing, Vol. 58, July, pp. 20-38.

Morgan, R.M. and Hunt, S.D. (1994), "The commitment-trust theory of relationship marketing”, Journal of Marketing, Vol. 58, July, pp. 20-38.

Moss, S., Prosser, H., Costello, H. (1998). Reliability and validity of the PAS-ADD Checklist for detecting psychiatric disorders in adults with intellectual disability. Journal of Intellectual Disability Research. 42, 173- 183.

Nunnally, JC. (1970). Introduction to Psychological Measurement. New York: McGraw-Hill.

Oliva, T.A., Oliver, R.L. and MacMillan, I.C. (1992), "A catastrophe model for developing service satisfaction strategies", Journal of Marketing, Vol. 56 No. 3, pp. 83-95.

Oliver, R.L. (1999), “Whence consumer loyalty?”, Journal of Marketing, Vol. 63, special issue, pp. 33-44. 
Rizwan, M., Zahid, S. A., Waseem, A., Faraz, H. M., Mushtaq, J., Anwaar, F. and Imran, I. (2013) Preceding To Permission Based Mobile Advertisement: An Empirical Study from Pakistan, IOSR Journal of Business and Management, Vol. 1 (special issue), 21-28

Reichheld, F. (1993), "Loyalty-based management", Harvard Business Review, Vol. 71, March-April, pp. 64-73.

Reichheld, F. and Sasser, W. (1990), "Zero defections: quality comes to service", Harvard Business Review, Vol. 68 No. 5, pp. 105-11.

Rizwan, M., Akbar, I., Muqtadir, A., Shafique, U., Zia, H., Naseer, W. and Amin, S. A. (2013) Impact of Brand Switching, Brand Credibility, Customer Satisfaction and Service Quality on Brand Loyalty, IOSR Journal of Business and Management, Vol. 1 (special issue), 12-20

Salam, A.F., Rao, H.R. and Pegels, C.C. (2003), "Consumer-perceived risk in e-commerce transactions", Communications of the ACM, Vol. 46 No. 12, pp. 325-31.

Stewart, K. (1998), “An exploration of customer exit in retail banking, International Journal of Bank Marketing, Vol. 16 No. 1, pp. 6-14.

Siddiqui, K. (2011), "Personality influences customer switching", International Journal of Contemporary Research in Business, Vol. 2 No. 10, pp. 363-72.

Trubik, E. and Smith, M. (2000), "Developing a model of customer defection in the Australian banking industry", Managerial Auditing Journal, Vol. 15 No. 5, pp. 199-208.

Venkatesh, V., \& Davis, F. D. (2000). A theoretical extension of the technology acceptance model: Four longitudinal field studies. Management Science, 46(2), 186-204.

Venkatesh, V., \& Davis, F. D. (2000). A theoretical extension of the technology acceptance model: Four longitudinal field studies. Management Science, 46(2), 186-204.

Weiss, A.M. and Anderson, E. (1992), “Converting from independent to employee sales forces: the role of perceived switching costs", Journal of Marketing Research, Vol. 29 No. 1, pp. 101-15.

Wieringa, J.E. and Verhoef, P.C. (2007), "Understanding customer switching behavior in a liberalizing service market”, Journal of Service Research, Vol. 10 No. 2, pp. 174-86.

Zeithaml, V.A., Berry, L.L. and Parasuraman, A. (1996), "The behavioral consequences of service quality", Journal of Marketing, Vol. 60 No. 2, pp. 31-46

Zeithaml, V.A., Parasuraman, A. and Berry, L.L. (1996), "The behavioral consequences of service quality”, Journal of Marketing, Vol. 60, April, pp. 31-46. Marketing, Vol. 62 No. 1, pp. $33-47$.

Zikmund, W.R. (1997). Business Research Methods (5th Ed.), Texas: The Dryden Press. 